\title{
Wokół jubileuszu sześćdziesięciolecia Katedry Dydaktyki Języka i Literatury Polskiej
}

Pozwólmy sobie z okazji jubileuszu na dość przewidywalny gest i porównajmy uczenie do sztuki budowania, która jak każda ars pozostawia miejsce na piękno, inwencję twórcy i dialog. Przestrzeń powstająca na styku tych wartości niewątpliwe służy spotkaniu. Katedra Dydaktyki Języka i Literatury Polskiej przez długie sześćdziesiąt lat kształciła przyszłych nauczycieli w przekonaniu, że nie tylko język polski jako przedmiot szkolny, ale i edukacja humanistyczna stwarzają dogodne warunki do spotkania. Zresztą ona sama była spotkaniem... ludzi, myśli i książek. Przez ponad pół wieku pozwalała myśleć o „,byciu u siebie", deklarując przy tym gotowość do przyjęcia tego, kto zgłasza wolę uczestniczenia w uniwersyteckiej/szkolnej/ludzkiej wspólnocie. I choć dziś po sześćdziesięciu latach Katedra Dydaktyki Języka i Literatury Polskiej przestaje istnieć, to przecież nie znikają idee, międzyludzkie więzi ani pamięć o niegdysiejszych śniegach. Wsłuchajmy się w głosy tych, którzy tą pamięcią zechcieli się podzielić.

Pracownicy byłej Katedry Dydaktyki Języka i Literatury Polskiej 